\title{
PENGGUNAAN ALAT PERAGA BERUPA KERTAS LIPAT UNTUK MENINGKATKAN PEMAHAMAN SISWA PADA MATERI BENTUK BILANGAN PECAHAN
}

\author{
Ahdin \\ SDN Cimeong Majalengka, Indonesia \\ ahdin68@gmail.com
}

\begin{abstract}
The fact shows that elementary mathematics learning is only for purposes that are in accordance with the curriculum, teachers tend to use monotonous learning techniques that make students less like math and consequently learning outcomes are low. The purpose of this study was to improve students' understanding of mathematics with fraction material using folding paper props in class IV SDN Cimeong students. The method used in this research is classroom action research conducted in 2 cycles. Data collection methods through observation, tests and demonstrations. The data analysis technique used is descriptive, qualitative and quantitative. Data collected in the form of student activities, teacher activities and individual tests. Based on data obtained from observations and test results, it can be concluded that students' understanding of fraction material has increased using folding paper props, can create active learning and stimulate students to discuss, issue opinions, motivate students to improve learning outcomes and can improve student familiarity.
\end{abstract}

Keywords: props; folding paper; understanding; elementary school student.

\begin{abstract}
ABSTRAK
Kenyataan menunjukkan bahwa pembelajaran matematika SD hanya untuk tujuan yang sesuai dengan kurikulum, guru cenderung menggunakan tehnik pembelajaran yang monoton sehingga membuat siswa kurang menyenangi pelajaran matematika dan akibatnya hasil belajar menjadi rendah. Tujuan dari penelitian ini untuk meningkatkan pemahaman siswa pada mata pelajaran matematika dengan materi pecahan dengan menggunakan alat peraga kertas lipat pada siswa kelas IV SDN Cimeong. Metode yang digunakan dalam penelitian ini adalah penelitian tindakan kelas yang dilakukan sebanyak 2 siklus. Metode pengumpulan data melalui observasi, tes dan demonstrasi. Tehnik analisis data yang digunakan adalah deskriptif, kualitatif dan kuantitatif. Data yang dikumpulkan berupa aktivitas siswa, aktivitas guru dan tes individu. Berdasarkan data yang diperoleh dari hasil observasi dan hasil tes diperoleh kesimpulan bahwa pemahaman siswa pada materi pecahan mengalami peningkatan dengan menggunakan alat peraga kertas lipat, dapat menciptakan pembelajaran yang aktif dan merangsang siswa untuk berdiskusi, mengeluarkan pendapat, memotivasi siswa untuk meningkatkan hasil belajar serta dapat meningkatkan keakraban siswa.
\end{abstract}

Kata Kunci: alat peraga; kertas lipat; pemahaman; siswa sekolah dasar.

$$
\text { Submitted Feb 2, } 2020 \text { | Revised Feb 18, } 2020 \text { | Accepted Feb 26, } 2020
$$

\section{Pendahuluan}

Matematika merupakan mata pelajaran yang mempunyai peranan penting dalam pendidikan. Hampir semua bidang studi memerlukan matematika. Oleh sebab itu, semua jenjang pendidikan harus mempelajari matematika agar dapat digunakan sebagai sarana untuk memecahkan masalah kehidupan sehari-hari, termasuk pada pendidikan tingkat dasar. 
Matematika memiliki peranan penting bagi kehidupan (Nahdi \& Jatisunda, 2020). Matematika perlu diberikan kepada siswa mulai dari sekolah dasar untuk membekali peserta didik dengan kemampuan berpikir logis, analitis, sistematis, kritis, dan kreatif, serta kemampuan bekerja sama. Kompetensi tersebut diperlukan agar peserta didik dapat memiliki kemampuan memperoleh, mengelola, dan memanfaatkan informasi untuk bertahan hidup pada keadaan yang selalu berubah, tidak pasti, dan kompetitif (Nahdi, 2017). Namun masih banyak siswa yang masih menganggap bahwa matematika sebagai mata pelajaran yang sangat sulit. Karakteristik matematika yang abstrak menjadikan siswa sulit memahami konsep-konsep dasar matematika. Hal ini berdampak pada rendahnya pemahaman siswa pada pembelajaran matematika. Rendahnya pemahaman siswa dalam konsep-konsep dasar matematika juga terjadi pada siswa kelas IV SDN Cimeong. Hasil tes dalam materi pecahan menggambarkan bahwa siswa-siswa tersebut masih kesulitan dalam memahami konsep pecahan. Oleh karena itu, dibutuhkan suatu media pembelajaran yang dapat mengubah konsep dasar pecahan yang abstrak menjadi lebih nyata, sehingga memudahkan siswa untuk memahaminya. Dalam hal ini, guru memiliki tugas berat untuk menciptakan pembelajaran yang mudah dipahami oleh siswa khususnya dalam menanamkan konsep-konsep dasar matematika. Peranan guru sangat menentukan karena kedudukannya sebagai pengelola pendidikan diantara siswa-siswa dalam kelas. Guru yang baik adalah guru yang mampu menjadi komunikator yang mengkomunikasikan materi pelajaran dalam bentuk verbal dan non-verbal serta menjadi fasilitator yang memiliki peran memfasilitasi siswa untuk belajar secara maksimal dengan mempergunakan strategi, metode, media, dan sumber belajar (Yamin, 2011).

Dalam pembelajaran Matematika yang abstrak, siswa memerlukan alat bantu berupa media, dan alat peraga yang dapat memperjelas apa yang akan disampaikan oleh guru sehingga lebih cepat dipahami dan dimengerti oleh siswa. Pada Matematika, setiap konsep yang abstrak dan baru dipahami siswa perlu segera diberi penguatan, agar mengendap dan bertahan lama dalam memori siswa, sehingga akan melekat dalam pola pikir dan pola tindakannya. Salah satu cara untuk menanamkan konsep-konsep matematika agar lebih mudah dipahami adalah dengan penggunaan media pembelajaran berupa alat peraga. Melalui penggunaan alat peraga ini, konsep abstrak matematika akan menjadi lebih nyata sehingga mudah dipahami. Menurut Trianto (2009) alat peraga pendidikan adalah suatu alat yang dapat diserap oleh mata dan telinga dengan tujuan membantu guru agar proses belajar mengajar siswa lebih efektif dan efisien. Alat peraga pendidikan sebagai instrument audio maupun visual yang digunakan untuk membantu proses pembelajaran menjadi lebih menarik dan membangkitkan minat siswa dalam mendalami suatu materi (Widada, 2010). Salah satu alat peraga yang dapat digunakan dalam pembelajaran materi pecahan adalah kertas lipat. Hasil studi yang dilakukan oleh Anggraini (2014), Daris, dkk. (2014), Setiawan (2016), menunjukkan alat peraga kertas lipat efektif dalam meningkatkan pemahaman siswa terhadap konsep-konsep dasar matematika.

Secara spesifik penulis menggunakan alat peraga kertas lipat dalam strategi pembelajaran untuk menanamkan pemahaman konsep pecahan. Alat peraga tersebut mampu menggambarkan beberapa bilangan dan mempu mengekspresikan terbentuknya suatu pecahan sehingga siswa lebih mudah dalam memahaminya. 


\section{Metode Penelitian}

Metode yang digunakan dalam penelitian ini merupakan Penelitian Tindakan Kelas. Penelitian Tindakan Kelas adalah proses pengkajian masalah pembelajaran di dalam kelas melalui refleksi diri dalam upaya untuk memecahkan masalah tersebut dengan cara melakukan tindakan yang terencana dalam situasi nyata serta menganalisis setiap pengaruh dari perlakuan tersebut Sanjaya (2011). Pendapat tersebut sesuai pendapat yang disampaikan oleh Kasbolah (2001: 15), bahwa Penelitian Tindakan Kelas merupakan penelitian tindakan dalam bidang pendidikan yang dilaksananakan dalam kawasan kelas dengan tujuan untuk memperbaiki dan atau meningkatkan kualitas pembelajaran.

Banyak model Penelitian Tindakan Kelas yang dapat diterapkan, tetapi dalam penelitian ini menggunakan model Kemmis dan McTaggart di mana dalam perencanaannya menggunakan siklus sistem spiral yang di dalamnya terdiri dari empat komponen, yaitu rencana, tindakan dan observasi serta refleksi (Sujati, 2000: 23).

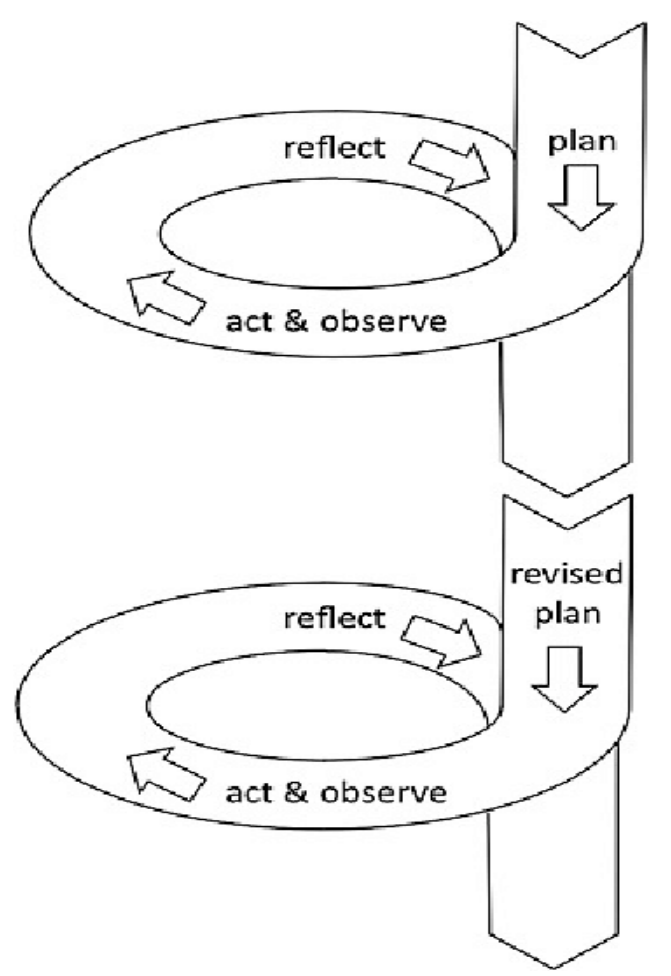

Gambar 1. Model kemmis dan Mc Taggart

Penelitian dilaksanakan di SDN Cimeong dengan subyek penelitian siswa kelas IV pada pembelajaran matematika materi pecahan. Data penelitian yang dikumpulkan berupa data observasi berupa pengamatan pengelolaan model pembelajaran dan pengamatan aktivitas siswa dan guru pada akhir pembelajaran, dan data tes formatif siswa pada setiap siklus.

Data lembar observasi diambil dari dua pengamatan yaitu data pelaksanaan pembelajaran matematika dengan media kertas lipat. Data tes formatif untuk mengetahui peningkatan pemahaman siswa setelah diterapkan media pembelajaran berupa alat peraga kertas lipat. 


\section{Hasil dan Pembahasan}

Pelaksanaan penelitian pada siklus I diawali dengan kegiatan pembelajaran matematika dilakukan tanpa menggunakan Alat Peraga, dengan tujuan ingin mengetahui sejauhmana kemampuan materi pembelajaran yang dimiliki oleh siswa. Adapun Pada siklus II, pembelajaran dilakukan dengan Alat Peraga, dengan tujuan melatih daya ingat / pengetahuan dalam materi pembelajaran yang diterima oleh siswa. Pada siklus III, pembelajaran dilakukan dengan Alat Peraga dan tanpa Alat Peraga yang ditetapkan, sehingga kemampuan siswa seperti yang diharapkan.

Guru melaksanakan pembelajaran selama 2 x 35 menit sesuai dengan desain yang disusun dengan langkah-langkah pembelajaran (1) Kegiatan awal 10 menit, (2) Kegiatan inti 45 menit, dan (3) Kegiatan akhir 15 menit, sesuai dengan prosedur yang telah tertuang dalam rencana pembelajaran.

Pada Siklus I pertemuan pertama, Siswa duduk ditempat masing-masing, guru memberikan pre tes tentang Matematika khususnya tentang bilangan pecahan. Selanjutnya guru menjelaskan secara lesan dengan berdasarkan buku paket, sedangkan siswa sambil mendengar juga membuka buku paket Matematika. Setelah kegiatan awal berakhir, siswa diberi Lembar Kerja Siswa (LKS) untuk diselesaikan dan selanjutnya dikumpulkan. Pada pertemuan kedua, Siswa duduk ditempat masing-masing, guru memberikan pre tes tentang Matematika khususnya tentang bilangan pecahan. Selanjutnya guru menjelaskan ulang seperti pada tatap muka yang ke I secara lesan dengan berdasarkan buku paket, sedangkan siswa sambil mendengar juga membuka buku paket matematika. Setelah kegiatan awal berakhir, siswa diberi Lembar Kerja Siswa (LKS) untuk diselesaikan dan selanjutnya dikumpulkan.

Pada siklus II pertemuan, duduk siswa diatur secara kelompok, ada lima kelompok, masing-masing kelompok terdiri dari 8 siswa. Sebelum kelompok diberikan LKS, guru menerangkan cara menggunakan Alat Peraga kertas lipat. Contoh mengerjakan soal melalui papan tulis diberikan berulang-ulang dan siswa diberi kesempatan untuk bertanya, bila ada yang kurang paham dalam menggunakan Alat Peraga kertas lipat. Setelah jelas dan dimengerti maka setiap kelompok diberi satu lembar LKS yang sudah direvisi untuk didiskusikan dan tiap kelompok sudah tersedia beberapa lembar kartu lipat. LKS yang diberikan siswa melalui kelompoknya, berisikan perintah untuk mengerjakan soal menghitung bilangan pecahan dengan, dimana kertas lipat yang sudah dibentuk sesuai dengan perintah soal langsung ditempelkan pada LKS dan bagian tertentu ditandai dengan arsiran / pensil warna..

Sebelum mengerjakan soal pecahan, siswa disuruh untuk mendekatkan diri / berkumpul pada kelompoknya terlebih dahulu, lalu siswa diperintahkan segera menyelesaikan soal yang diberikan dengan waktu yang telah ditentukan harus berakhir selesai maupun tidak. Setelah waktu yang ditentukan berakhir, siswa diperintahkan untuk segera menyerahkan LKSnya dan duduk pada bangkunya masing-masing. Dengan cepat pula guru mengumumkan hasil / nilai yang diperoleh oleh kelompoknya. Selanjutnya siswa ditugaskan untuk mengerjakan dan latihan soal dengan menggunakan Alat Peraga kertas lipat dirumah dengan kerja kelompok.

Pada pertemuan kedua, siswa menempati tempat duduknya sendiri, guru meminta kelompok untuk mengumpulkan hasil pekerjaan rumahnya. Selanjutnya guru membagikan LKS beserta Alat Peraga kertas lipat kepada masing-masing siswa, dengan waktu yang 
ditentukan siswa langsung mengerjakan dan mengumpulkan hasilnya kepada guru (selesai atau tidak). Berikutnya guru membahas beberapa kertas lipat hasil pekerjaan siswa dan beberapa soal pecahan ditulis dipapan oleh guru, bagi siswa yang bisa segera mengacungkan jarinya untuk menjawab. Guru secara adil memberikan kesempatan pada yang lain (yang belum menjawab) secara bergiliran kepada semua siswa.

Secara umum, keseluruhan tindakan dapat menjadi indikasi bahwa upaya peningkatan kemampuan tentang bilangan pecahan dapat dilakukan dengan baik. Hasil evaluasi menunjukkan bahwa kemampuan siswa tentang pecahan melalui Alat Peraga kertas lipat ada peningkatan yang signifikan dari siklus pertama ke siklus berikutnya.

Tabel 1. Hasil Tes Akhir Pada Siklus I

\begin{tabular}{llc}
\hline No. & Kategori & Jumlah \\
\hline 1 & Siswa Tuntas & $16(59,3 \%)$ \\
2 & Siswa Belum Tuntas & $11(40,7 \%)$ \\
3 & Rata-rata & 69,4 \\
\hline
\end{tabular}

Data hasil observer pada Siklus I masih menunjukkan bahwa kurangnya mengoptimalkan metode mengajar, identifikasi masalah pembelajaran di kelas ditemukan bahwa siswa kelas IV Guru SD Negeri Cimeong Kecamatan Banjaran Kabupaten Majalengka, hasil belajarnya belum optimal karena masih menggunakan model pembelajaran konvensional. Berdasarkan permasalahan tersebut disusun perencanaan pembelajaran melalui Alat Peraga kertas lipat. Selama pembelajaran dilakukan observasi dan pengukuran hasil pembelajaran sebagai bahan refleksi. Dalam refleksi diperoleh kesimpulan bahwa pembelajaran melalui Alat Peraga alat bantu pada Siklus I, masih banyak siswa yang belum mampu, maka dilakukan perencanaan pembelajaran yang baru sesuai dengan sumber permasalahannya.

Dari data tersebut setelah dianalisa kemudian diadakan evaluasi dan refleksi selanjutnya hasil siklus II sebagai rekaman data observasi sebagai berikut:

Tabel 2. Hasil Tes Akhir Pada Siklus II

\begin{tabular}{llc}
\hline No. & Kategori & Jumlah \\
\hline 1 & Siswa Tuntas & $25(92,6 \%)$ \\
2 & Siswa Belum Tuntas & $2(7,4 \%)$ \\
3 & Rata-rata & 76,1 \\
\hline
\end{tabular}

Dari data di atas dapat disimpulkan bahwa pembelajaran matematika tentang konsep pecahan cukup berhasil. Hal ini terlihat dari jumlah siswa yang tuntas mencapai 92,6\%. Berdasarkan hasil dialog dan wawancara diperoleh gambaran bahwa dengan menggunakan Alat Peraga kertas lipat, anak tampak lebih cepat dan bersemangat mengerjakan soal-soal dan merasakan bahwa belajar sambil bermain menggunakan Alat Peraga, lebih cepat dan mudah mengerjakan soal-soal yang diberikan guru. 


\section{Kesimpulan}

Media berupa alat peraga kertas lipat mampu menjembatani karakteristik matematika yang abstrak menjadi lebih nyata, khusunya pada materi pecahan. Hal ini didasarkan pada hasil penelitian yang menunjukan adanya peningkatan pemahaman siswa dari mulai siklus I hingga siklus terakhir.

\section{Daftar Pustaka}

Anggraini, N. (2014). Meningkatkan Hasil Belajar Melalui Media Kerlip (Kertas Lipat) Pada Materi Konsep Kelipatan Bilangan Pada Siswa Kelas IV SDN Bantelan Sumenep. Pedagogia, 3(2), 136-147.

Daris, H, Halini, Hanye, P. (2014). Peningkatan Hasil Belajar Matematika Menggunakan Alat Peraga Kertas Lipat pada Peserta Didik. Jurnal Pendidikan dan Pembelajaran Untan, 3(6).

Hudojo, H. (1990). Strategi Belajar Mengajar Matematika. Malang: Ikip .

Kasbolah, K. (2001). Penelitian Tindakan Kelas (PTK). Malang: Depdikbud.

Nahdi, D.S. (2017). Implementasi Model Pembelajaran Collaborative Problem Solving Untuk Meningkatkan Kemampuan Representasi Matematis Siswa Sekolah Dasar. Jurnal Cakrawala Pendas, 3(1), 6-15.

Nahdi, D. S., \& Jatisunda, M. G. (2020). Conceptual Understanding And Procedural Knowledge: A Case Study on Learning Mathematics of Fractional Material in Elementary School. Journal of Physics: Conference Series, 1477, 42037. https://doi.org/10.1088/1742-6596/1477/4/042037

Sanjaya, W. (2011). Penelitian Tindakan Kelas. Jakarta: Kencana Prenada. Media Grup.

Setiawan, I. (2016). Peningkatan Hasil Belajar Matematika Pada Materi Pecahan Siswa Kelas III SD Negeri Bendungan III Dengan Alat Peraga Kertas Lipat. Jurnal Pendidikan Guru Sekolah Dasar, 5(3), 214-226.

Sujati. (2000). Penelitian Tindaka Kelas. Yogyakarta. FIP. UNY

Trianto. (2009). Mendesain Model Pembelajaran Inovatif Progresif. Jakarta: Kencana

Widada. (2010). Mudah Membuat Media Pembelajaran Multimedia Interaktif. Yogyakarta: Pustaka Widyatama.

Yamin, M. (2011). Paradigma Baru Pembelajaran. Jakarta; Gaung Persada Press. 